\title{
Práxis educativa das professoras alfabetizadoras de Cascavel - Ceará
}

\author{
Lia Machado Fiuza Fialho' \\ Scarlett O'hara Costa Carvalho ${ }^{2}$ \\ Marília Carvalho dos Santos ${ }^{3}$
}

\section{RESUMO}

A alfabetização universal das crianças até o final dos primeiros anos do Ensino Fundamental ainda é um problema no Brasil e em várias cidades do país, como é o caso de Cascavel, no Ceará. O objetivo foi compreender que correntes pedagógicas orientam as práticas educativas utilizadas pelas professoras alfabetizadoras, que atuam em classes de $1^{\circ}, 2^{\circ}$ e $3^{\circ}$ ano, da Escola Júlia de Melo. Desenvolveu-se uma pesquisa de abordagem qualitativa, do tipo estudo de caso, que utilizou a história oral temática como metodologia. As entrevistas, enquanto instrumento de coleta de dados, permitiram gravar, transcrever, textualizar e validar as narrativas orais das três professoras alfabetizadoras que trabalham na escola investigada. Os resultados revelaram que todas as professoras iniciaram a docência como professoras leigas, no entanto, realizaram a licenciatura em Pedagogia em regime especial pela Universidade Vale do Acaraú, com recursos próprios. As atuações como alfabetizadoras deram-se sem qualquer formação específica. Apenas uma professora identificou a corrente pedagógica que orientava suas práticas, o construtivismo. As demais, além de demonstrarem desconhecimento, adotavam práticas sintéticas e tradicionais, culpabilizando o aluno e

1 Doutora em Educação Brasileira pela Universidade Federal do Ceará. Pós-doutora em Educação pela Universidade Federal da Paraíba. Pós-doutoranda em Educação pela Universidade de Salamanca. Professora do Centro de Educação da Universidade Estadual do Ceará. Professora do Programa de Pós-graduação em Educação (PPGE/UECE) e do Mestrado Profissional em Planejamento e Políticas Públicas (MPPP/UECE). Líder do Grupo de Pesquisa Práticas Educativas Memórias e Oralidades - PEMO. Editora da revista Educação \& Formação do PPGE/UECE. Orcid: http://orcid.org/0000-0003-0393-9892. E-mail: lia_fialho@yahoo.com. br

2 Doutoranda pelo programa de Pós-Graduação em Educação da Universidade Estadual do Ceará (PPGE/UECE). Mestre em Educação (UECE). Pesquisadora do grupo de pesquisa Práticas Educativas, Memórias e Oralidades (PEMO), bolsista CAPES. Orcid: http://orcid. org/0000-0002-0381-0063. E-mail: scarlettoharacc@gmail.com

3 Graduada em Pedagogia pela Universidade Estadual do Ceará. Professora do Colégio Cascavelense. Orcid: https://orcid.org/0000-0001-7997-3515. E-mail:mariliasantos1916@ gmail.com 
suas famílias pelo fracasso escolar. Importa fomentar formação contínua com mote na reflexão e ressignificação da práxis educativa.

Palavras-chave: Alfabetização. Práticas educativas. História oral.

\section{Educational praxis of literacy teachers in Cascavel - Ceará}

\section{ABSTRACT}

The universal literacy of children until the end of the first grades of elementary school is still a problem in Brazil and in several cities in the country, as it is the case of Cascavel, in Ceará. The objective was to understand which pedagogical currents guide the educational practices used by literacy teachers, who work in grades 1, 2 and 3, at Escola Júlia de Melo. A qualitative research was developed, in the type of case study, which used thematic oral history as a methodology. The interviews, as a data collection instrument, allowed to record, transcribe, textualize and validate the oral narratives of the three literacy teachers who work in the investigated school. The results revealed that all teachers started teaching as lay teachers, however, they did a degree in Pedagogy in a special regime by the Universidade Vale do Acaraú, with their own resources. The performances in literacy took place without any specific training. Only one teacher identified the pedagogical current that guided her practices, constructivism, the others, in addition to demonstrating ignorance, adopted synthetic and traditional practices, blaming the student and their families for school failure. It is important to promote continuous training with a view to reflecting on and re-signifying educational praxis.

Keywords: Literacy. Educational practices. Oral history.

\section{Praxis educativa de las profesoras alfabetizadoras de Cascavel - Ceará}

\section{RESUMEN}

La alfabetización universal de los niños hasta el final de los primeros años de la Enseñanza Fundamental aún es un problema en Brasil y en varias ciudades del país, como es el caso de Cascavel, en Ceará. El objetivo fue comprenderquecorrientes pedagógicas orientan las prácticas educativas utilizadas por las profesoras alfabetizadoras, que actúan en aulas de $1^{\circ}$, 
$2^{\circ}$ y $3^{\circ}$ año de la Escuela Júlia de Melo. Se desarrolló una investigación de abordaje cualitativo, del tipo estudio de caso, utilizando la historia oral temática como metodología. Las entrevistas en cuanto instrumento de recogida de datos permitieron grabar, transcribir, textualizar y validar las narrativas orales de las tres profesoras alfabetizadoras que trabajan en la escuela investigada. Los resultados evidenciaron que todas las profesoras comenzaron la docencia sin formación, pero realizaron el curso de Pedagogía en régimen especial por la Universidad Vale do Acaraú con recursos propios. Las actuaciones como alfabetizadoras ocurrieron sin formación específica. Solamente una profesora identificó la corriente pedagógica que orientaba sus prácticas, el constructivismo. Otras profesoras, además de demostrar desconocimiento, adoptaban prácticas sintéticas y tradicionales, echando culpa al alumnado y a sus familias por el fracaso escolar. Interesa fomentar formación continuada enfocada en la reflexión y resignificación de la praxis educativa.

Palabras clave: Alfabetización. Prácticas educativas. Historia oral.

\section{Introdução}

Ao estudar sobre a temática alfabetização é possível perceber que, desde seu nascimento, o homem apresentava dificuldade para se comunicar, pois é inserido em uma sociedade que utiliza a fala, os gestos, os grafemas e outras possibilidades para se expressar. Dessa maneira, desde a mais tenra idade, a criança vai aprendendo como efetivar sua comunicação (SANTO; OLIVEIRA JÚNIOR, 2020). Assim sendo, segundo Solé (1998, p. 50), a alfabetização emergiu como um processo pelo qual se aprende a ler e a escrever, "[...] estes procedimentos, porém, vão muito além de certas técnicas de translação da linguagem oral para a linguagem escrita". Tal afirmação permite inferir que a alfabetização extrapola a simples prática de escrita e decodificação, já que se inter-relaciona com a interpretação do que se lê e escreve, envolvendo um arcabouço de conhecimentos previamente adquiridos e a realidade em que se insere o indivíduo.

O ato de alfabetizar ganha importância a cada dia nas sociedades, o que resulta na constituição de ambientes com esse mote principal: as escolas. Essa instituição constituiu-se lócus privilegiado para desenvolver a alfabetização, todavia, entende-se que esta como "um processo contínuo, que acompanha uma ação mais ampla de busca em 
construção de conhecimentos, inerente a todo ser humano que vive numa sociedade letrada" (GARCIA, 1992, p. 10), logo, o processo de alfabetização ultrapassa o ambiente escolar e não se efetiva em apenas um ano da educação formal.

De acordo com Ferraz e Mendonça (2007) a aprendizagem da leitura e da escrita como temos hoje, só foi padronizada no final do século XIX mediante a criação de diferentes métodos de alfabetização, denominados sintéticos e analíticos. Sobre esses tipos de métodos, Carvalho (2015, p. 18, grifos das autoras) assegura que:

Durante muito tempo, discutiu-se que métodos se-
riam mais eficientes: se os sintéticos, (que partem da
letra, da relação letra-som, ou da sílaba, para chegar à
palavra), ou os analíticos, também chamados globais
(que têm como ponto de partida unidades maiores
da língua, como o conto, a oração ou a frase).

O método sintético ainda é muito presente na prática dos professores no momento da alfabetização, pois desde as antigas "Cartilhas do $A B C$ ", muitas gerações foram alfabetizadas a partir do alfabeto e das letras, numa perspectiva silábica (LICAR, 2012). Esse método estabelece uma correspondência entre o som e a grafia, entre o oral e o escrito, por meio do aprendizado de letra por letra, sílaba por sílaba e palavra por palavra. Já no que concerne ao método analítico, concorda-se com Frade, (2007), quando leciona que este consiste em trabalhar primeiro os elementos maiores como o texto e as frases para depois chegar às unidades menores como as palavras e as sílabas, valorizando o conhecimento prévio do aluno e o seu contexto sociocultural.

Importa destacar também o construtivismo como método apoiado nas ideias de Piaget $(1970,1975)$, que subsidiou um arcabouço de teoria, indicativa de práticas utilizadas no campo educacional, muitas vezes transformada em métodos pedagógicos para aplicação em determinados aspectos da aprendizagem escolar (SANCHIS; MAHFOUD, 2010). Destaca-se que não foi o intuito de Piaget elaborar métodos educativos, no entanto, suas ideias foram amplamente utilizadas e adaptadas ao campo educacional. Emília Ferreiro (2001), ao estudar os processos de aquisição da linguagem escrita pelas crianças, na relação entre o real e a representação, explica que a escrita não é a simples cópia de um modelo, mas um processo de construção desenvolvido pela criança. Nessa perspectiva, a alfabetização é compreendida como objeto do co- 
nhecimento, adquirido culturalmente nas construções individuais dos alunos.

Na perspectiva construtivista, o aluno é compreendido como "[...] um sujeito que procura adquirir conhecimento, e não simplesmente de um sujeito disposto ou mal-disposto a adquirir uma técnica particular" (FERREIRO; TEBEROSKY, 1986, p. 11). Desse modo, o aprendiz torna-se sujeito ativo na construção do conhecimento e não apenas mero receptor de informações estáticas e descontextualizadas com mote na memorização acrítica.

$\mathrm{Na}$ atualidade, independentemente do método escolhido, é consensual a importância de se alfabetizar levando em consideração o contexto social em que o aprendiz está inserido, pois, além de aprender a ler e a escrever, interessa que os estudantes sejam capazes de refletir sobre o que estão lendo e escrevendo (GENÚ, 2018). Consoante a essa compreensão, Bottentuit Júnior, Menez e Wunsch, (2019) destacam o conceito de letramento, já que não basta a aquisição da utilização de técnicas codificadoras para escrever ou técnicas decodificadoras para ler. É necessário compreender o sentido do que se lê ou do que se escreve. Interpretação esta que exige conhecimento de mundo.

Compreende-se que alfabetização e letramento são processos indissociáveis, e que para o último ser efetivado é necessário passar por um processo de alfabetização, que, na maioria das vezes, mediado por professores nas instituições escolares que não podem tolher a criatividade do educando (LIMA; SANTOS, 2018). Vasconcelos, Fialho e Lopes (2018) destacam a importância para o desenvolvimento de uma educação com o objetivo de promover a liberdade, que não se assenta no disciplinamento, o que torna possível fomentar um ambiente de aprendizagem prazeroso e dinâmico. Isto posto, subjacente às práticas de qualquer professor, observa-se a mobilização de um conjunto de ideias que as orientam, ou seja, de uma tendência pedagógica que interfere na seleção dos métodos utilizados para alfabetizar, que podem variar na atuação de cada educador. Dessa compreensão emerge a questão central propulsora dessa pesquisa: Quais correntes pedagógicas orientam as práticas educativas das professoras alfabetizadoras da escola pública Júlia de Melo situada na cidade de Cascavel, no Ceará?

Para responder a essa inquietação, desenvolveu-se um estudo com o objetivo de compreender que correntes pedagógicas orientam 
as práticas educativas utilizadas pelas professoras alfabetizadoras que atuam em classes de $1^{\circ}, 2^{\circ}$ e $3^{\circ}$ ano, da Escola Júlia de Melo.

Importa salientar que no Ceará, a média do Índice de Desenvolvimento da Educação Básica (Ideb) para as séries iniciais foi de 6,28 em 2017, e a média do município de Cascavel, o Ideb ficou acima do Estado com 6,4 (IBGE, 2017). Inclusive, algumas escolas de Cascavel alcançaram média de 7,6, como a Escola Maria Montessori e a Escola Hercules Bosquirelli (QEDU, 2017). No entanto, a escola Júlia de Melo ficou com índice 5.0, abaixo da média do município e do estado, mesmo estando localizada em uma região central da cidade, possuindo número reduzido de alunos por turma e contando com boa estrutura física (QEDU, 2017).

Ainda que o Ideb não seja considerado determinante da qualidade da educação de uma instituição escolar por se tratar de uma avaliação em larga escala que não leva em consideração as diversidades regionais e locais, ele é um indicador do aprendizado dos alunos. Inquieta, todavia, saber mais sobre a alfabetização desenvolvida na Escola Júlia de Melo para compreender se há nuances nesse processo que podem ter colaborado para que os alunos obtivessem um rendimento no aprendizado inferior à média do município.

A pesquisa aqui apresentada torna-se relevante por proporcionar visibilidade acerca de uma temática bastante discutida no campo educacional, a alfabetização. No entanto, ultrapassa questões puramente teóricas que ressaltam a práxis das alfabetizadoras, considerando seus processos formativos e suas narrativas sobre a maneira como mobilizam seus saberes para trabalhar a escrita e a leitura com as crianças (ALVES; FIALHO, 2019). A partir das narrativas docentes, substrato desse estudo, torna-se factível analisar com profundidade um caso específico na perspectiva qualitativa, o que não se faz possível em pesquisas macro, de cunho quantitativo. Fialho e Sousa (2019) destacam que não apenas é possível compreender o todo pelas partes, como a relevância de desenvolver estudos científicos que levem em consideração as subjetividades e nuances não captadas em investigações macro históricas, pois o que importa na pesquisa não é o tamanho da amostra e sua representatividade, mas a riqueza dos detalhes e a possiblidade de lançar luz às vozes, por vezes, ignoradas ou silenciadas.

O artigo está subdividido em cinco seções: 1) "Introdução", que explanou a temática e sua delimitação, bem como o problema de pesquisa, o objetivo, a relevância do estudo e sua organização; 2) “Educação 
formal e alfabetização", tópico no qual se elucida conceitos preliminares para possibilitar a compreensão das discussões dos resultados; 3) "Metodologia", em que é apresentado o percurso investigativo da pesquisa, destacando-se a abordagem, o tipo de estudo, o instrumento de coleta de dados e os aspectos éticos, bem como o lócus da pesquisa e a forma de participação dos colaboradores; 4) "Resultados e Discussões", seção em que são apresentados os resultados das entrevistas seguidos de sua discussão; e 5) "Considerações finais", que se retoma o problema e o escopo do estudo proposto respondendo-os sucintamente e copilando as principais ideias emergentes com a pesquisa e apontando as limitações e sugestões para novas pesquisas.

\section{Educação e alfabetização}

A educação é um fenômeno social inerente à constituição do homem em sociedade, integrante, portanto, da vida social, econômica, política, cultural (LIBÂNEO, 2010). É por meio dela que os indivíduos assimilam e trocam saberes, habilidades, técnicas e valores com seus pares. "Educar por sua vez, no seu sentido epistemológico, é conduzir de um estado para o outro, é agir de maneira sistemática sobre o ser humano, tendo em vista prepará-lo para a vida num determinado meio" (PLANCHARD, 1975, p. 26).

A educação, ante essa compreensão, tem papel importante para o ser humano por tratar-se de um processo social permanente que se desenvolve ao longo da vida. Todavia, o estudo em tela não desconsidera o quão abrangente é o processo educativo, mas centra ênfase numa faceta específica, a alfabetização realizada na educação formal. No que concerne aos tipos de educação, Libâneo (2010, p. 31) classifica:

Educação formal: claramente estruturada, propiciada por entidades que pertencem ao chamado sistema formal de educação e treinamento, reconhecido por entidades governamentais, oferecendo certificação. A outra é Educação não-formal: visivelmente estruturada, propiciada por instituição que não pertencem ao chamado sistema formal de educação e treinamento, como associações, ONGs e empresa. E por fim a Educação informal que acontece em lugares não estruturados para esse fim, ela ocorre ao longo de toda a vida, adquirida através de contatos pessoais, observação de situações, uso do computador. 
Carvalho, Fialho e Vasconcelos (2017) destacam que a educação informal é aquela que acontece de forma espontânea no seio familiar e social de maneira não intencional, já a educação não formal, por sua vez, pode ser entendida como qualquer tentativa de desenvolver intencionalmente a atividade educativa fora do sistema formal de ensino, como em ambientes culturais. Ainda que ambas sejam indissociáveis à educação formal, esta última caracteriza-se de maneira diferenciada, pois desenvolve-se de maneira intencional, planejada, sistematizada, em ambiente e horário pré-determinados, com o objetivo de trabalhar conhecimentos e saberes já produzidos socialmente. Gohn (2006) acrescenta que a escola tornou-se, neste caso, o lócus mais preponderante para veicular a educação formal.

Por investigar o processo de alfabetização desenvolvido na escola regular, o estudo trabalha com a educação formal transcorrida na escola, ensejando luz aos sujeitos da pesquisa, que são professoras alfabetizadoras, em seus contextos de trabalho, atuando de forma intencional e sistemática, com objetivos pré-definidos (LIBÂNEO, 2010). Afinal, a alfabetização escolar caracteriza-se como importante instrumento para desenvolver a capacidade de comunicação escrita pela criança, isso porque está relacionada diretamente ao domínio da utilização dos símbolos linguísticos e sua interpretação. Segundo Carvalho (2015), em decorrência, uma pessoa bem alfabetizada conhece o código alfabético, domina as relações grafônicas e sabe, não apenas que os sons representam as letras, mas, o significado das mensagens por elas veiculadas.

As experiências alfabetizadoras, narradas pelas professoras, permitem compreender singularidades nos caminhos tecidos pelas educadoras polivalentes ${ }^{4}$ na tentativa de alfabetizar crianças para que estas possam tornar-se alunos que cheguem ao ensino médio capazes de compreender criticamente os textos, afinal, Josefi (2011) destaca a importância de leitores críticos. Na contramão, é comum que os estudantes recém-alfabetizados consigam ler decodificando os símbolos, mas somente isso não é o suficiente, necessita-se que sejam preparados para entenderem o que estão lendo de maneira reflexiva. Diante disso, o processo de alfabetização requer muita atenção, já que é a base que conduzirá a criança à aquisição da leitura e da escrita, ou seja, do letramento.

4 Polivalente é um construto utilizado para designar o professor que assume a responsabilidade pelo ensino de várias disciplinas. 
Soares $(2017$, p. 23) constata que "o fracasso em alfabetização persiste, embora esse fracasso, agora, configure-se de forma diferente", logo, importa desenvolver estudos que problematizem tal mazela social:

\begin{abstract}
O fracasso na década inicial do século XXI é denunciado por avaliações externas à escola - avaliações estaduais, nacionais e até internacionais -, e já não se concentra na série inicial da escolarização, mas espraia-se ao longo de todo o ensino fundamental, chegando mesmo ao ensino médio, traduzido em altos índices de precário ou nulo domínio da língua escrita, evidenciando grandes contingentes de alunos não alfabetizados ou semialfabetizados depois de quatro, seis, oito anos de escolarização.
\end{abstract}

Para resolver esse problema, Mortatti (2014, p. 75) questiona: "Como alfabetizar? Por onde começar? Pelos nomes das letras, pelos sons das letras, pelas sílabas, por palavras-chave, por sentenças ou por histórias?". Ao escutar o professor alfabetizador, considerando seu processo formativo, as técnicas desenvolvidas e a corrente pedagógica que o orienta, é possível perceber as dificuldades e os mecanismos de superação, bem como possibilitar uma reflexão sobre a prática docente para qualificar a práxis educacional. Essa proposta está afinada com as ideias de Piaget $(1970,1975)$, já que não há uma receita pronta para o desenvolvimento do processo alfabetizatório, pois varia de acordo com o ritmo e desenvolvimento de cada criança e das suas condições materiais e imateriais, como assevera o construtivismo.

Segundo Soares (2017), os métodos adotados para fomentar a aprendizagem inicial da língua escrita são conjuntos de procedimentos que, com base em teorias e princípios linguísticos e psicológicos, orientam essa aprendizagem em cada uma de suas facetas. $O$ autor destaca que durante muitos anos o foco das discussões sobre alfabetização recaía em torno desses métodos, no entanto, em meados da década de 1980 um novo paradigma ultrapassou a perspectiva dos métodos sintéticos e analíticos, o construtivismo. A discussão transcende o fato de a aprendizagem ser mais eficiente da parte para o todo ou do todo para a parte, pois infere um aprendizado centrado no aluno, em respeito ao ritmo do seu desenvolvimento, levando em consideração suas singularidades e seu contexto. Ferreiro e Teberosky (1986), inclusive, já inferiam que na perspectiva construtivista o professor passou a ser percebido como o mediador do conhecimento, e não mais como o detentor desse 
conhecimento, sendo o aluno estimulado a criar e a construir seu conhecimento.

Independentemente do método adotado, o fim é o letramento com qualidade, ou seja, uma alfabetização que possibilite ao aluno ultrapassar a mera condição de receptor, codificador e decodificador de informações, para tornar-se um aprendiz que utiliza os conhecimentos para interpretar sua realidade e intervir de maneira responsável. Soares (1998, p. 20) explicita que:

[...] passamos a enfrentar esta nova realidade social em que não basta apenas saber ler e escrever, é preciso saber fazer uso do ler e do escrever, saber responder às exigências de leitura e de escrita que a sociedade faz continuamente.

Dessa maneira, "letrado é alguém que se apropriou suficientemente da leitura e da escrita a ponto de usá-las com desenvoltura, com propriedade, para dar conta de suas atribuições sociais e profissionais" (CARVALHO, 2015, p. 66). Para isso, faz-se necessário uma alfabetização contextualizada, pois:

\footnotetext{
Alfabetizar e letrar são duas ações distintas, mas não inseparáveis, ao contrário: o ideal seria alfabetizar letrando, ou seja: ensinar a ler e escrever no contexto das práticas sociais da leitura e da escrita, de modo que o indivíduo se tornasse, ao mesmo tempo, alfabetizado e letrado (SOARES, 1998, p. 47).
}

A alfabetização escolar, nessa perspectiva, enquanto movimento inerente à educação formal constitui-se de um processo inicial de letramento, bastante complexo, que precisa ser mediado com qualidade, por intermédio de uma práxis consciente, sistematizada, com objetivo previamente planejado. Cabe entender, todavia, quais as correntes pedagógicas que orientam as práticas educativas das professoras alfabetizadoras da escola pública Júlia de Melo, a partir dos métodos de ensino adotados, para captar lacunas e possibilidades na atuação alfabetizadora nos primeiros anos do Ensino Fundamental.

\section{Metodologia}

Esse estudo, consoante Fialho, Lima e Queiroz (2019), autores que desenvolvem pesquisas educacionais com professoras, em especial 
biografias, defende que as subjetividades de pessoas comuns, como mulheres docentes, importam para compreender os processos educativos. Logo, buscou-se investigar uma realidade microssocial de uma única escola, o que fez com que a pesquisa apropriasse-se da abordagem qualitativa amparada em Minayo (1994), e do estudo de caso descrito por Gil (2002) e Yin (2001), que utilizou a história oral temática como metodologia de coleta e análise de dados. Yin (2001, p. 32) esclarece acerca da importância dos estudos de caso qualitativos por tornar factível "uma investigação empírica que investiga um fenômeno contemporâneo dentro de seu contexto da vida real, especialmente quando os limites entre o fenômeno e o contexto não estão claramente definidos".

A história oral temática utilizada como metodologia, defendida por Meihy e Holanda (2007), parte de um projeto pré-definido com o uso de oralidades como fonte de pesquisa. Esse estudo, nessa direção, desde um projeto prévio elaborado com o objetivo de compreender que correntes pedagógicas orientam as práticas educativas utilizadas pelas professoras alfabetizadoras, respaldou-se em um grupo social específico: educadoras que atuam em classes de $1^{\circ}, 2^{\circ}$ e $3^{\circ}$ ano, da Escola Júlia de Melo. As narrativas foram coletadas mediante entrevistas em história oral, sobre um tema gerador - desenvolvimento da alfabetização de crianças - com três perguntas norteadoras: 1. Qual a sua formação para atuar como professora alfabetizadora?; 2 . Como ingressou nessa atividade?; 3. Que práticas desenvolve para alfabetizar as crianças?.

As respostas às entrevistas foram gravadas e transcritas, em seguida, textualizadas e validadas pelas entrevistadas, que tiveram a oportunidade de suprimir vícios de linguagem ou acrescentar pequenas informações com o objetivo de tornar a leitura mais fluida. O objetivo foi captar uma narrativa, elaborada mediante lembranças e esquecimentos, que aferiam a uma versão sobre a percepção que as professoras tinham sobre a alfabetização de crianças. Dessa maneira, compreende-se, consoante Fialho, Lopes e Brandenburg, (2016), que a memória é o substrato da história oral, pois a partir dessa memória das alfabetizadoras foi possível compreender conexões entre o presente e o passado, bem como interpretações no tempo presente.

A seleção dos participantes da pesquisa considerou, como critério de inclusão, professores que atuassem nas primeiras séries do ensino fundamental ( $1,2^{\circ}$ e $3^{\circ}$ ano) na Escola Júlia de Melo, pelo fato de que essas séries são importantes no trabalho com a alfabetização, pois espe- 
ra-se que ao final desses anos o aluno possa estar letrado para escrever e interpretar textos simples. Identificaram-se três professoras, que por razões éticas tiveram suas identidades preservadas e, por conseguinte, consoante à resolução $n^{\circ} 510$ de abril de 2016, os colaboradores receberam nomes fictícios: Débora, Simone e Maria.

O lócus da pesquisa selecionado foi a Escola Júlia de Melo situada em Cascavel, no Ceará. Essa instituição é considerada uma conquista para a comunidade, pois faz parte da história educacional do município pelo pioneirismo na oferta do segundo grau desde 1992. De acordo com o Projeto Político Pedagógico (PPP) da escola, desde o início do funcionamento até o ano de 1995, havia apenas o $2^{\circ}$ grau (ensino médio), mas a partir de 1996 começou a funcionar como escola de $1^{\circ}$ e $2^{\circ}$ graus, conforme o decreto $\mathrm{N}^{\circ} 028 / 96$ de 08 de novembro de 1996, pelo prefeito municipal Carlos Thadeu Queiroz Rocha. Seus alunos sempre foram majoritariamente de classes populares, moradores de bairros próximos, não diferente de muitas outras escolas públicas do Brasil.

A Escola Júlia de Melo está localizada na Rua Bia Coelho, s/n, bairro Bessalândia, e atende crianças e adolescentes dos bairros Planalto, Parque Urupê, Centro e adjacências. Segundo consta no seu PPP, o principal objetivo da escola é uma educação de qualidade para todos, embasada no respeito, na ética, na solidariedade e na justiça. A instituição, no entanto, possui Ideb abaixo da média municipal e estadual, com $8 \%$ de distorção entre série e idade e problemas no que concerne à alfabetização e ao letramento dos alunos. Na contramão, a escola possui boa infraestrutura por contar com: 14 salas de aulas, sala de diretoria, sala de professores, sala de recursos multifuncionais para Atendimento Educacional Especializado (AEE), quadra de esportes coberta, cozinha, sala de leitura (biblioteca), banheiro adequado aos alunos com deficiência ou mobilidade reduzida, sala de secretaria, despensa, almoxarifado e pátio coberto. Ademais, funciona com uma razoável quantidade de alunos por turma, com média respectiva de 18, 20 e 24 alunos para as turmas de $1{ }^{\circ}, 2^{\circ}$ e $3^{\circ}$ anos (ESCOLAS, 2017).

O acesso à escola foi realizado mediante prévia autorização, por parte da gestão pedagógica, após análise da carta de apresentação e do Termo de Consentimento Livre e Esclarecido (TCLE). Com o aval da coordenadora, adentrou-se à escola e contatou-se pessoalmente com as professoras dos anos iniciais do Ensino Fundamental $\left(1^{\circ}, 2^{\circ}\right.$ e $3^{\circ}$ ano) para a realização do convite para colaboração com a pesquisa. Todas aceitaram 
prontamente. Em seguida, agendaram-se os dias, os horários e o local para a realização das entrevistas, neste caso, a própria escola. As entrevistas em história oral foram coletadas durante o mês de março de 2019, sendo realizadas com Débora e Simone no dia 12 e com Maria no dia 20.

$\mathrm{Na}$ data previamente agendada, realizou-se a leitura e explicação do TCLE, explicando-se o objetivo da pesquisa, bem como a metodologia, forma de participação das entrevistadas, possíveis riscos, ausência de benefícios, liberdade de recusa, participação voluntária, possibilidade de desistência a qualquer momento, forma de divulgação dos resultados, dentre outros aspectos éticos. Após assinatura do TCLE, desenvolveu-se a entrevista, que foi gravada em equipamento digital, transcrita literalmente, textualizada e validada pelas professoras.

Utilizando a história oral não apenas como "uma prática de apreensão de narrativas feitas através do uso de meios eletrônicos" (MEIHY; HOLANDA, 2007, p. 18), mas como metodologia de análise dessas oralidades, as narrativas foram trabalhadas individualmente considerando todos os seus detalhes, em seguida, separando-se os trechos mais representativos acerca da temática - desenvolvimento da alfabetização de crianças - para discussão. A seleção dos recortes narrativos levou em consideração a formação para atuar como professora alfabetizadora, a forma de ingresso na docência e as práticas que desenvolviam para alfabetizar as crianças.

\section{Resultados e discussões}

Todas as entrevistadas nasceram em Cascavel, interior do Estado do Ceará, e conhecem a realidade educacional da cidade e dos alunos, ou seja, possuem uma visão crítica acerca do contexto social, econômico e cultural dos alunos. Duas delas, Simone e Maria, respectivamente com 29 e 45 anos, cursaram toda a educação básica na rede pública de ensino e Débora, com 41 anos, cursou a educação infantil em creche pública de bairro, ingressando, em seguida, na escola particular, onde concluiu sua educação básica.

Considerando que a experiência formativa vivenciada interfere no desenvolvimento das práticas alfabetizadoras, buscou-se conhecer o processo de alfabetização das professoras. Débora, ao asseverar que as lembranças são permeadas por esquecimentos, traz à tona suas memórias: 
O que eu lembro, faz tanto tempo, né? E que quando eu estudava, não tinha infantil, era jardim, eu lembro assim, que eu fiz o jardim I e o jardim II, e depois a gente tinha que fazer a alfabetização. Eu estudava na escola pública, mas depois do jardim II minha mãe foi me matricular aqui na $\mathrm{CNEC}^{5}$. Era uma escola que tinha aqui, eu lembro que tinha que fazer um teste que era para saber se eu acompanhava a alfabetização ou primeiro ano, aí nesse teste já me colocaram para o primeiro ano, eu não fiz alfabetização. Eu sei que a minha mãe conta assim, eu lembro também, que era para eu ir para a alfabetização e já fui para o primeiro ano. O que eu lembro assim, desse processo [...] (DÉBORA, 12/03/2019).

Débora lembra que cursou o jardim de infância em uma escola pública e que depois sua mãe matriculou-a em uma escola particular, em que ela pulou logo para o primeiro ano, não passando pela série específica para alfabetização, pois já tinha aprendido a ler e a escrever, ainda no jardim II, na escola onde estudava. Sua memória não permitiu recordar as práticas de alfabetização da sua época. Já Simone, a mais nova entrevistada, explica com mais detalhes seu processo de alfabetização, inclusive, fazendo analogia aos tempos atuais:

A minha alfabetização foi muito diferente da de hoje, pois hoje as aulas são bem participativas, no meu tempo não era assim. Hoje em dia se trabalha mais com o concreto, diferente da minha época. Faltava material, era mais lousa e caderno, a gente não tinha jogos pedagógicos. Não digo que foi ruim, mas eu acho que hoje é bem melhor, as coisas são bem mais acessíveis e atrativas. Até a questão do acesso, né! As mídias na escola também facilitam isso, para que nós possamos trazer um diferencial para o aluno e trabalhar também com eles em sala de aula (SIMO$\mathrm{NE}, 12 / 03 / 2019)$.

Simone conta que sua alfabetização foi realizada por meio de aulas pouco participativas e envolventes, que utilizavam como principais recursos pedagógicos a lousa, o giz, o caderno, o lápis e a borracha. Salienta que não havia jogos pedagógicos ou recursos tecnológicos e

5 A Campanha Nacional de Escolas da Comunidade surgiu em 1943, na cidade de Recife, como Campanha do Ginasiano Pobre. Chegou ao Ceará em 1958 e fundando mais de 80 escolas cerca de 40 municípios cearenses. 
que a educação era muito abstrata, sem considerar a realidade em que o aluno estava inserido. Segundo Freire (2017) tratava-se da educação bancária, na qual o professor, detentor do conhecimento, era mero transmissor de informações e ao aluno cabia a recepção mnemônica e mecânica de conhecimentos estáticos, desprovidos de análise crítica.

Ananias e Santos (2019) chamam atenção para a comparação entre práticas educativas de 20 anos atrás e as práticas atuais sem considerar os aspectos específicos das temporalidades, pois pode constituir-se um anacronismo histórico. No entanto, a narrativa é importante para mostrar que a educação não é estática, e, em consequência desse dinamismo, importa refletir sobre as correntes pedagógicas adotadas em cada tempo, assim como as práticas educativas empreendidas.

O relato de Maria também chamou atenção para algumas diferenças nas práticas das professoras em tempos distintos:

Hoje nós temos uma mudança muito grande, muito grande, porque eu não fui da época da palmatória não, graças a Deus, e nem do chapéu de burro (risos). Mas com certeza antigamente a gente tinha dificuldade, dificuldade muito grande de estudar, que hoje graças a Deus, aqui em Cascavel, nós contamos com 65 escolas, na minha época se tivesse 10 escolas era muito, tinha particular, que na época aqui em Cascavel a gente contava com a CNEC (MARIA, 20/03/2019).

A palmatória era um objeto característico dos primórdios da educação tradicional, feito de madeira, com aparência de uma grande colher, que servia para bater na palma da mão dos alunos que não decoravam as informações transmitidas pelos professores ou desrespeitasse preceitos disciplinares. Já o chapéu de burro, segundo Lopes (2017), consistia em colocar na cabeça do aluno uma marca pública do seu fracasso, ou seja, o chapéu servia para expor publicamente o aluno caracterizado como burro por não dominar determinado conhecimento, constrangendo-o e servindo de exemplo a não ser seguido pelos demais. Essas técnicas eram características da corrente tradicional e possuíam o objetivo de repreender os alunos que não conseguiam assimilar as informações a contento.

Maria explica que em sua época, a dificuldade de estudar era muito grande, pois existiam poucas escolas na cidade, especialmente para cursar o secundário (ensino médio), por ser ofertado em institui- 
ção particular. Farias (2018), ao discutir a história do Ceará, aponta as deficiências da educação no estado, de tal maneira que, sem transporte escolar, com precárias condições financeiras e sem apoio do poder público, a maior parte da população interiorana do Ceará, da década de 1980, não conseguia deslocar-se até a escola e manter-se matriculada no secundário, parando de estudar ao final do primário ou no ensino ginasial.

Como não havia universidade ou faculdade no munícipio, as professoras conseguiram acesso ao curso superior por meio de uma graduação em regime especial certificada pela Universidade Estadual Vale do Acaraú - UVA, única oferta de ensino superior em Cascavel durante muitos anos. Núcleos credenciados, com fins privados, ofereciam cursos de licenciatura aos finais de semana e nas férias, com duração de apenas dois anos, para diplomar professores, com mensalidades a baixo custo e qualidade questionável. Esses cursos foram importantes para regularizar a situação de muitos professores leigos que lecionavam sem a devida formação pedagógica, que passou a ser exigida após a publicação da Lei de Diretrizes e Bases da Educação Nacional, LDB 9394/96 (BRASIL, 1996), no entanto, foi bastante questionado no que concerne à qualidade da formação.

Em relação à escolha do curso de Pedagogia, Maria relata:

\begin{abstract}
A minha família toda, toda é pedagoga, vêm da minha mãe, vêm das minhas tias, vêm das minhas irmãs, quer dizer, eu sou a terceira geração. Já na nova geração, eu tenho sobrinho, tem meu filho que é estudante de fisioterapia, tenho as minhas sobrinhas, que dizer, escolheram outras profissões. A única das filhas, das sobrinhas, da terceira geração que faltava era eu, aí eu peguei, um belo dia, um plano $B$, eu já conhecia e ficava na sala, antes de eu ser professora, aí aquilo me fez ver que era isso que eu queria. Como tem o ditado, nunca é tarde, né! Eu fiquei fascinada por esse mundo de ensinar (MARIA, 20/03/2019).
\end{abstract}

A narrativa de Maria infere sobre uma questão cultural histórica, a feminização do magistério, assunto discutido por Michele Perrot (2017). Observa-se que ela cita apenas as figuras femininas das gerações anteriores atuando como professoras, pois, como destaca Vasconcelos, Fialho e Machado (2018), para a mulher, a docência com crianças era considerada uma extensão da maternidade, pois não desvirtuava das 
funções sociais vinculadas ao sexo feminino: esposa prendada, dona de casa, mãe dedicada. Não diferente das outras gerações, Maria começou a atuar na docência como professora leiga por influência da família e foi identificando-se com a profissão.

Débora, assim como Maria, mencionou que sua mãe também era professora e que a incentivou a entrar na docência. Já Simone, escoIheu a Pedagogia por ter sido a oportunidade de trabalho que surgiu e pela facilidade de fazer uma graduação na área, já que só havia cursos de licenciatura ofertados pelo sistema especial da UVA.

Maria é a única entrevistada que possui somente a graduação, pois licenciou-se recentemente e não cogitava a possibilidade de fazer pós-graduação. As outras duas entrevistadas fizeram pós-graduação: Débora cursou especialização em Psicopedagogia e Simone, Gestão Escolar. As três professoras são contratadas pela prefeitura de Cascavel, Débora e Simone em regime de 200h, distribuídas nos períodos manhã e tarde, e Maria em regime de $100 \mathrm{~h}$ trabalhando apenas no período da tarde. Todas fizeram seleção para ingressarem na escola, mas nenhuma é concursada porque faz anos que o município está impossibilitado de fazer concurso, devido a irregularidades no último edital.

Sobre o ingresso como alfabetizadora, Débora, a professora com maior tempo de atuação na prefeitura, iniciando no ano de 2013, explica:

\begin{abstract}
Foi um desafio muito grande, porque a primeira turma que eu peguei era multisseriada, primeiro e segundo ano juntos, quando eu iniciei estava no mês de março porque ninguém queria ir para essa turma. Eu queria trabalhar, né? Estava terminando Pedagogia, a gente quer logo é botar em prática o que a gente está aprendendo. [...] A ordem era puxar para a série mais adiantada, aí pense, aqueles alunos que estavam no primeiro ano você ter que puxar eles para acompanhar no livro do segundo ano! (DÉBORA, 12/03/2019).
\end{abstract}

Observa-se que Débora começou a alfabetizar de maneira empírica, sem qualquer experiência com o ensino e sem a formação inicial concluída. A turma multisseriada, muito comum nas cidades do interior do Ceará, consistia em reunir alunos em idade e nível de aprendizagem diferentes em uma mesma sala de aula sob a responsabilidade de um único professor, o que possibilitava reduzir a demanda por professores. No entanto, tornava o trabalho de alfabetizar ainda mais difícil, pois, não 
bastasse a falta de formação dos professores, ainda era necessário adaptar o ensino às singularidades dos alunos ante uma compreensão de que era o aluno quem deveria adequar-se ao ensino do professor, como constatado nos estudos de Mendes, Fialho e Machado (2019) e Fialho, Sousa e Nascimento (2020).

Já Simone, iniciou na área da educação como monitora na Educação infantil em uma creche do município de Cascavel, na turma do infantil III, em regime de tempo integral. Depois passou a lecionar como professora de crianças dos anos iniciais do Ensino Fundamental: "Eu fui para o primeiro ano, no primeiro ano eu passei dois anos. Depois eu fui para o segundo ano" (SIMONE, 12/03/2019). Ainda que tenha começado a lecionar antes da conclusão da graduação, ela infere que a experiência como monitora ajudou bastante, não evitando, pois, dificuldades no exercício da alfabetização, para o qual não havia experiência alguma. Já Maria, iniciou a docência durante o $4^{\circ}$ semestre do curso de Pedagogia, em uma escola conveniada com a prefeitura de Cascavel, para substituir uma professora que saiu de licença maternidade, e permaneceu na escola por mais quatro anos.

Sobre a importância da articulação entre teoria e prática, Lima (2001, p. 36) leciona que: "Quando vamos ensinando, vendo o que não dá certo e tentando acertar, quando voltamos a estudar e procuramos levar esses ensinamentos para nossa realidade estamos fazendo a práxis educativa". Nesse sentido, enfatiza que refletir sobre a prática docente é importante, mas a reflexão exige revisitar a teoria para qualificar a prática. No caso das três professoras observou-se que o ingresso na atividade alfabetizadora foi precipitado, e que elas tiveram que aprender empiricamente, com os próprios acertos e erros, o que impossibilitava uma práxis crítica e reflexiva amparada teoricamente em sólida base teórica. Dessa forma, elas foram reproduzindo as práticas alfabetizadoras que vivenciaram ou mesmo as práticas que observavam, sem definir conscientemente a corrente pedagógica que iria subsidiar suas práticas.

Atualmente, quando questionadas acerca dessa temática, Simone diz que trabalha com o construtivismo e relata:

Eu gosto de trabalhar com o construtivismo, porque é assim, a criança ela se torna o ator principal, ela é quem desenvolve ali, as ações. O professor ele está 
ali para fazer as mediações entre eles, mas eles mesmos é quem constroem. E com isso você, além de trabalhar o processo de alfabetização, trabalha as responsabilidades e o espírito de liderança que é muito importante. A criança aprende a ser proativa, por isso eu gosto muito de trabalhar com o construtivismo. (SIMONE, 12/03/2019).

Já Débora e Maria, não identificaram a corrente pedagógica que orienta suas práticas, mas tentaram explicar como trabalham a alfabetização. A primeira relata: "Assim, eu gosto sempre de pensar assim, que cada criança é um ser, todas vão aprender. Mas vão todas aprender na mesma hora, no mesmo tempo? Não. Cada criança tem o seu tempo, agora o importante é a gente nunca desistir" (DÉBORA, 12/03/2019). Já Maria infere que:

Tipo assim, eu uso muito a criatividade. O meu método de alfabetização, a gente ganha um material todo bonitinho, um planejamento do ano todo da Secretaria de Educação, aí eu pego, passo para o meu caderno, certo [mostra o caderno com o planejamento]. Aí tem aquele professor que você vai decidir qual você vai ser, se aquele professor dedicado, entendeu? Que não aceita 10 crianças lendo e 10 não lendo, ou você vai ser aquele professor que tanto faz como tanto fez, eu estou aqui, vou ganhar meu dinheiro mesmo. Eu não sou esse tipo, e não quero jamais ser, entende? (MARIA, 20/03/2019).

Simone demonstra que conhece as correntes pedagógicas e tenta embasar-se no construtivismo, inclusive, mostra vários materiais concretos que comprara com recursos próprios na tentativa de desenvolver um ensino lúdico, atrativo e contextualizado, por exemplo, o castelo de ditados, cantinho da leitura, painel com os gêneros textuais, o caminhão de atividades, dentre outros. Ela compreende-se como mediadora da aprendizagem e percebe o aluno como epicentral no processo da alfabetização, respeitando tempos e ritmos variados; como pressupõe o construtivismo segundo Ferreiro (2001).

As salas de aula da Débora e Maria não apresentam muitos recursos que proporcionem um ambiente alfabetizador, existindo apenas um alfabeto ilustrado, alguns cartazes e um cantinho da leitura, que fazem inferência ao trabalho com o método sintético, partindo de unidades menores para unidades maiores e mais complexas. 
Claro que a metodologia não é mais a questão central ou a mais importante na área da alfabetização, mas quem se propõe a alfabetizar, baseado ou não no construtivismo, deve ter conhecimento básico sobre os princípios teórico-metodológicos da alfabetização, para não ter que inventar a roda (CARVALHO, 2015, p. 17).

Mesmo que as professoras não utilizem uma corrente pedagógica específica, como assevera Tancredi e Reali, (2011), é importante que elas estejam cientes da teoria que envolve a alfabetização e dominem a prática para que possam desenvolver um trabalho que permitam às crianças construírem o conhecimento. No entanto, Débora e Maria, ainda que se mostrem dispostas a ensinar e a fazer o aluno aprender, desenvolviam métodos tradicionais, caracterizados por utilizar materiais prontos, atividades com sílabas, palavras, frases e textos, sequencialmente, que não eram contextualizadas com a realidade dos alunos e não despertavam o interesse das crianças. Essas educadoras atribuíam o fracasso da leitura e da escrita ao desinteresse e preguiça dos alunos, bem como à falta de acompanhamento da família, no entanto, geralmente as atividades desenvolvidas em sala de aula centram-se mais no livro e na lousa, não despertando no aluno a curiosidade propulsora da descoberta de conhecimentos (PEREZ, 2012).

Ferreiro (2001, p. 30-31) ressalta a importância das práticas didáticas com as quais a criança é introduzida na língua escrita:

\begin{abstract}
Há práticas que levam a criança à convicção de que o conhecimento é algo que os outros possuem e que só se pode obter da boca dos outros, sem nunca ser participante na construção do conhecimento. Há práticas que levam a pensar que "o que existe para se conhecer" já foi estabelecido, como um conjunto de coisas fechado, sagrado, imutável e não-modificável. Há práticas que levam a que o sujeito (a criança neste caso) fique de "fora" do conhecimento, como espectador passivo ou receptor mecânico, sem nunca encontrar respostas aos "porquês" e aos "para quês" que já nem sequer se atreve a formular em voz alta.
\end{abstract}

Importa destacar a necessidade pela formação continuada, assunto já discutido, por exemplo, por Fialho, Machado e Sales (2014) e Mororó (2017), para que as professoras possam qualificar suas práticas alfabetizadoras e embasá-las teoricamente, com vistas a não reproduzi- 
rem a ideia, na criança, de que o conhecimento é algo alheio a ela, estático e inquestionável. Nesse sentido, destaca-se a importância de desenvolver formações contínuas, que possam discutir as correntes teóricas características de cada momento histórico, suas finalidades, as práticas características de cada uma delas e diversas maneiras de constituir uma práxis contextualizada e de qualidade.

Junges, Ketzer e Oliveira (2018) realizam um estudo que trata da formação continuada de professores, mostrando que esta pode possibilitar a ressignificação de saberes na perspectiva de promover práticas docentes transformadas. No entanto, ainda que de relevância inconteste, somente a formação continuada não é capaz, sozinha, de resolver todos os problemas imbricados na educação formal de qualidade, pois como destaca Smyth e Hamel (2016) a formação inicial de professores é preocupação mundial e carece de aprimoramento para que os professores estejam mais qualificados ao iniciar o docência. Esta não pode ser concebida de maneira mecânica, ao contrário, precisa ser pautada em uma práxis responsável, qualificada e que, segundo Dinarte e Corazza (2016), não perde de vista o espaço poético como tradução didática, pois as experiências estéticas e criativas precisam ser incentivadas.

Fomentar uma educação pautada nos princípios de justiça social, no combate ao fracasso escolar e na formação para o exercício da cidadania crítica é assunto discutido por inúmeros pesquisadores sob múltiplas perspectivas e em diversos contextos (ARAÚJO; ESTEVES, 2017; BANFIELD; HADUNTZ; MAISURIA, 2016; BOMFIM, 2015; PEREIRA; RIBEIRO, 2017). Estes possuem a congruência de perceber a educação como importante veículo para a transformação da sociedade e, nessa perspectiva, como elemento central para impulsionar equidade e igualdade. Todavia, sem a oferta de uma educação de qualidade para todos, independente da condição econômica e social, aprofunda-se o fosso da desigualdade no Brasil.

Constatou-se uma tendência de as professoras mais velhas, participantes desse estudo, reproduzirem muitas das práticas pedagógicas vivenciadas em seus processos educativos, logo, concorda-se com Mesquita e Cardoso (2019) e com Waschinewski e Rabelo (2019) que facultar momentos de reflexão coletivos acerca da práxis pode fomentar outros olhares e novas compreensões acerca da complexidade do processo alfabetizatório, bem como possibilitar descobertas sobre as várias técnicas para diversificar atividades com ênfase na leitura e na escrita, ressignificando o ensinar 
e o aprender com o objetivo de minimizar o fracasso escolar e alcançar meIhores índices educacionais a partir de uma práxis educativa consciente.

\section{Considerações finais}

O estudo partiu de uma inquietação acerca de quais eram as correntes pedagógicas utilizadas pelas professoras alfabetizadoras da escola pública Júlia de Melo para orientar as suas práticas. Isso porque havia o pressuposto de que ao escutar as alfabetizadoras considerando seus processos formativos, as técnicas didáticas desenvolvidas e as correntes pedagógicas que as orientavam, seria possível perceber dificuldades e mecanismos de superação, subsidiando reflexão acerca das práticas docentes adotadas com o mote de qualificá-las.

Desenvolveu-se um estudo de caso com o objetivo de compreender que correntes pedagógicas orientavam as práticas educativas utilizadas pelas professoras alfabetizadoras, que atuam em classes de $1^{\circ}$, $2^{\circ}$ e $3^{\circ}$ ano, da Escola Júlia de Melo. A partir da metodologia da história oral temática, foi possível conhecer como se deu o processo de alfabetização das professoras, o ingresso na docência, a aquisição da formação inicial e as práticas adotadas para mediar a alfabetização.

Observou-se que na década de 1980, período de escolarização de duas das professoras, o acesso à educação no município de Cascavel era restrito, pois não havia escolas públicas de fácil acesso ao ensino secundário. Muitas mulheres, que queriam uma profissão, iniciavam a atividade docente sem formação específica para o magistério e ensinavam às crianças adotando empiricamente as mesmas práticas que haviam vivenciado no seu período de escolarização. Em consequência, reproduziam atividades mnemônicas, descontextualizadas, pouco atrativas aos alunos, que utilizavam a lousa e o caderno como principal recurso didático para reprodução, por meio de cópia e de atividades dos livros didáticos.

Todas as três professoras eram leigas, até aparecer no município uma instituição privada, conveniada com a UVA, que oferecia o curso superior de Pedagogia em regime especial, com duração de dois anos e aulas durante as férias e aos finais de semana. Essa formação inicial, ainda que habilitasse para a docência, não foi suficiente para fornecer o amparo teórico necessário para apoiar uma práxis dinâmica e contextualizada. Maria não procurou formação continuada, Débora e Simone, 
perceberam a necessidade de ampliar a formação e fizeram especialização, no entanto, no caso de Simone o curso de especialização em Psicopedagogia não refletiu em mudanças significativas nas suas práticas, já empreendidas há anos da mesma maneira.

As duas professoras mais velhas - Maria e Débora - não conseguiram identificar quais correntes teóricas orientavam suas práticas pedagógicas e permaneciam adotando métodos de ensino semelhantes aos vivenciados em seus tempos de alunas da educação básica, excluindo-se apenas o uso da palmatória e do chapéu de burro. Já Simone, a educadora mais jovem, especialista em Gestão Escolar, apontava o construtivismo como a corrente teórica que orientava suas práticas, e demonstrou tanto em seu discurso como na organização e no aparelhamento da sala de aula, com recursos didáticos, que tentava efetivar uma práxis dinâmica, atrativa, contextualizada, centrada nos alunos, imbuída do espírito criativo e investigador.

Não havia momentos profícuos para as professoras socializarem e discutirem sobre suas práticas, de modo que cada uma ministrava suas aulas como consideravam mais oportuno. Ainda que aparentemente preocupadas com o aprendizado dos alunos, as professoras não diversificavam a maneira de ensinar e não refletiam criticamente sobre as suas ações docentes com o mote de ressignificar a práxis pedagógica ou ampliar o arcabouço teórico, que poderia amparar cientificamente suas escolhas metodológicas.

Exceto Simone, que buscava apoio teórico no construtivismo, as outras professoras utilizavam a técnica sintética para a alfabetização, notadamente na perspectiva da corrente tradicional, sem articulação entre teoria e prática. $\mathrm{E}$, mesmo que todas as educadoras concordassem que atualmente o acesso das crianças à escola era mais facilitado e que os recursos pedagógicos foram ampliados largamente, elas em nenhum momento mencionaram como essa modernização ressignifica as práticas pedagógicas e que tipo de aluno estavam querendo formar desde uma perspectiva de alfabetizar letrando.

Sabe-se, todavia, que não há receita pronta para alfabetizar, mas é consensual que esse processo considere o contexto dos alunos e fomente possibilidades criativas de descoberta que ultrapassam a simples codificação e decodificação. Torna-se necessário, com efeito, o investimento em formação contínua de professores que mobilizem reflexões sobre as práticas pedagógicas, possibilitando a experimentação de no- 
vas maneiras de mediar o conhecimento, efetivando uma práxis reflexiva. Assim, talvez, as docentes possam encontrar coletivamente mecanismos para superar os problemas de alfabetização, inclusive, articulando família e escola a fim de minimizar a culpabilização do fracasso escolar aos próprios alunos e a suas famílias.

Importa destacar que essa pesquisa, por se tratar de um estudo de caso, possui a limitação de não poder ser generalizada, no entanto, é relevante porque seus resultados colaboram para tensionar políticas públicas municipais de formação docente, bem como valorizar a educação e os profissionais do magistério.

\section{Referências}

ALVES, F. C.; FIALHO, L. M. F. Currículo na educação infantil: O que pensam os professores? Práxis educacional, v. 15, p. 251-272, 2019. Disponível em: http://periodicos2.uesb.br/index.php/praxis/index Acesso em: 23 maio 2020.

ANANIAS, M.; SANTOS, L. R. “Quando o homem sabe ler, escrever e contar, pode, por sua própria individualidade, desenvolver - se e esclarecer-se": a escolarização de crianças pobres na província da Parahyba do Norte (1855-1866). Educação \& Formação, v. 4, n. 10, p. 66-80, 2019. https:// revistas.uece.br/index.php/redufor/article/view/453 Acesso em: 23 mai. 2020.

ARAÚJO, R. M. B.; ESTEVES, M. M. F. A formação docente, inicial e contínua, para o trabalho com adultos em Portugal: o olhar dos professores. Educação \& Formação, v. 2, n. 4, p. 18-35, 2017. Disponível em: https:// revistas.uece.br/index.php/redufor/article/view/121/104 Acesso em: 10 out. 2019.

BANFIELD, G.; HADUNTZ, H.; MAISURIA, A. The (im)possibility of the intellectual worker inside the neoliberal university. Educação \& Formação, v. 1, n. 3, p. 3-19, 2016. Disponível em: https://revistas.uece. br/index.php/redufor/article/view/110/93 Acesso em: 10 out. 2019.

BOMFIM, J. A. O Ensino de Língua Portuguesa: das controvérsias teóricas à institucionalização do fracasso via avaliações estandardizadas. Revista Educação e Emancipação, v. 8, n. 2, p. 36-62, 2015. Disponível em http://www.periodicoseletronicos.ufma.br/index.php/ 
reducacaoemancipacao/article/view/4213/3399 Acesso em: 23 mai. 2020.

BOTTENTUIT JÚNIOR, J. B.; CORREA SÁ MENEZ, M. R.; WUNSCH, L. P. Aplicativos móveis para a alfabetização e letramento no contexto do Ensino Fundamental. Revista Tempos e Espaços em Educação, v. 11, n. 01, p. 37-56, 2019. https://seer.ufs.br/index.php/revtee/article/ view/9812 Acesso em: 23 maio 2020.

BRASIL. Ministério da Educação. Lei n. 9.394, de 20 de dezembro de 1996. Estabelece as diretrizes e bases da educação nacional. Diário Oficial da União: Brasília, DF, 23 dez. 1996. Disponível em: http://www.planalto. gov.br/ccivil_03/Leis/L9394.htm Acesso em: 24 de mai. de 2020.

CARVALHO, M. Alfabetizar e letrar: um diálogo entre a teoria e a prática.12 ed. Rio de Janeiro: Vozes, 2015.

CARVALHO, S. O. C.; FIALHO, L. M. F.; VASCONCELOS, J. G. O Pedagogo na Assistência Social. Fortaleza: EdUECE, 2017.

DINARTE, L. D. R.; CORAZZA, S. M. Espaço poético como tradução didática: Bachelard e a imagem da casa. Educação \& Formação, v. 1, n. 2, p. 135-148, 2016. Disponível em: https://revistas.uece.br/index.php/ redufor/article/view/105/87 Acesso em: 10 de out. 2019.

ESCOL.AS. Júlia de Melo. 2017. Disponível em: https://www.escol. as/62363-julia-de-melo Acesso em: 17 mai. 2020.

FARIAS, A. História do Ceará. 7 ed. Fortaleza: Armazém da Cultura, 2018. FERRAZ, C.; MENDONÇA, M. Alfabetização e letramento: conceitos e relações. Belo Horizonte: Autêntica, 2007.

FERREIRO, E. Reflexões sobre alfabetização. 24 ed. São Paulo: Cortez, 2001.

FERREIRO, E.; TEBEROSKY, A. Psicogênese da Língua Escrita. Porto Alegre: Artes Médicas, 1986.

FIALHO, L. M. F.; LIMA, A. M. S.; QUEIROZ, Z. F. Biografia de Aída Balaio: prestígio social de uma educadora negra. Educação Unisinos, v. 23, p. 48-67, 2019. Disponível em: http://revistas.unisinos.br/index.php/ educacao/article/view/edu.2019.231.04 Acesso em: 23 maio 2020.

FIALHO, L. M. F.; LOPES, T. M. R.; BRANDENBURG, C. (Org.). Educação, 
memórias e narrativas. Fortaleza: EdUECE, 2016.

FIALHO, L. M. F.; SOUSA, F. G. A.; NASCIMENTO, L. B. S. Biografia da educadora Josete Sales: reflexos da formação de professoras no Ceará. Roteiro, v. 45, 2020. Disponível em: https://portalperiodicos.unoesc. edu.br/roteiro/article/view/23790 Acesso em: 23 mai. 2020.

FIALHO, L. M. F.; SOUSA, F. G. A. Juventudes e redes sociais: interações e orientações educacionais. Revista Exitus, v.9, p.202,2019. Disponível em: http://www.ufopa.edu.br/portaldeperiodicos/index.php/revistaexitus /article/viewFile/721/421 Acesso em: 23 maio 2020.

FIALHO, L. M. F; MACHADO, C. J. S; SALES, J. A. M. As correntes do pensamento geográfico e a Geografia ensinada no Ensino Fundamental: objetivos, objeto de estudo e a formação dos conceitos geográficos. Educação em Foco, v. 17, p. 203-224, 2014. Disponível em: http://revista. uemg.br/index.php/educacaoemfoco/article/view/432/355 Acesso em: 23 mai. 2020.

FRADE, I. C. A. S. Métodos de alfabetização, métodos de ensino e conteúdos da alfabetização: perspectivas históricas e desafios atuais. Educação, Santa Maria, v. 32, n. 1, p. 21-40, 2007. Disponível em: https://periodicos.ufsm.br/reveducacao/article/view/658 Acesso em: 23 maio 2020.

FREIRE, P. Pedagogia do Oprimido. 63. ed. Rio de Janeiro: Paz e Terra, 2017.

GARCIA, R. L. Alfabetização dos alunos das classes populares. São Paulo: Cortez, 1992.

GENÚ, M. S. A abordagem da ação crítica e a epistemologia da práxis pedagógica. Educação \& Formação, v. 3, n. 9, p. 55-70, 2018. Disponível em: https://revistas.uece.br/index.php/redufor/article/view/856/758 Acesso em: 10 de out. 2019.

GIL, A. C. Como elaborar projetos de pesquisa. 4 ed. São Paulo: Atlas, 2002.

GOHN, M. G. Educação não-formal na pedagogia social. In: I CONGRESSO INTERNACIONAL DE PEDAGOGIA SOCIAL, 2006. Proceedings online... Faculdade de Educação, Universidade de São Paulo, Disponível em: http://www.proceedings.scielo.br/scielo.php?script=sci_arttext\&pid 
$=$ MSC0000000092006000100034\&lng=en\&nrm=abn Acesso em: 24 maio 2020.

IBGE-Instituto Brasileiro de Geografia e Estatística. IBGE cidades. 2017. Disponível em: https://cidades.ibge.gov.br/brasil/ce/cascavel/panorama . Acesso em: 23 mai. 2020.

JOSEFI, A. H. B. Leitura e escrita: como a escola tem ensinado? Rev. Acolhendo a Alfabetização nos Países de Língua Portuguesa, v. 1, n. 10. p. 181 - 201. 2011. Disponível em: http://www.acoalfaplp.net Acesso em: 10 dez. 2019.

JUNGES, F.C.; KETZER, C. M.; OLIVEIRA, V. M. A. de. Formação continuada de professores: saberes ressignificados e práticas docentes transformadas. Educação \& Formação, Fortaleza, v. 3, n. 9, p. 88-101, 2018. Disponível em: https://revistas.uece.br/index.php/redufor/article/view/858/760 Acesso em: 10 de out. 2019.

LIBÂNEO, J. C. Pedagogia e pedagogos, para quê? 12 ed. São Paulo: Cortez, 2010.

LICAR, A. C. N. C. A Questão de Livros da Escola-Modelo Benedito Leite: cultura material escolar e poder disciplinar no Maranhão (19001911). Revista Educação e Emancipação, v. 5, n. 1, p. 198. 2012. Disponível em: http://www.periodicoseletronicos.ufma.br/index.php/ reducacaoemancipacao/article/view/5366 Acesso em: 10 de out. 2019.

LIMA, J. S.; SANTOS, G. L. dos. Valores, educação infantil e desenvolvimento moral: concepções dos professores. Educação \& Formação, v. 3, n. 8, p. 153-170, 2018. Disponível em: https://revistas.uece.br/index.php/ redufor/article/view/275/203 Acesso em: 10 de out. 2019.

LIMA, M. S. L. A hora da prática: reflexões sobre o estágio supervisionado e ação docente. 2 ed. Fortaleza: Edições Demócrito Rocha, 2001.

LOPES, J. P. Análise semiótico-psicanalítica de uma representação visual da burrice no ensino-aprendizagem de matemática. Ciênc. Educ., v. 23, n. 1, p. 237-254, 2017. Disponível em: https://www.scielo.br/pdf/ciedu/ v23n1/1516-7313-ciedu-23-01-0237.pdf Acesso em: 10 de out. 2019.

MEIHY, J. C. S. B.; HOLANDA, F. História oral: como fazer, como pensar. São Paulo: Contexto, 2007. 
MENDES, M. C. F. ; FIALHO, L. M. F. ; MACHADO, C. J. S. . Argentina Pereira Gomes: disseminação de -inovações- didáticas na educação primária na década de 1930. Revista Diálogo Educacional, v. 19, p. 527-550, 2019. Disponível em: https://periodicos.pucpr.br/index.php/ dialogoeducacional/article/viewFile/24959/23519 Acesso em: 17 de mai. 2020.

MESQUITA, M. R.; CARDOSO, W. R. S. O pacto pela venda da escola pública no Pará. Revista Educação e Emancipação, v. 12, n. 1, p. 317-334, 2019. Disponível em: http://www.periodicoseletronicos.ufma.br/index.php/ reducacaoemancipacao/article/view/10758/6242 Acesso em: 17 de mai. 2020.

MINAYO, M. C. S. (Org.). Pesquisa social: teoria, método e criatividade. 6. ed. Petrópolis: Vozes, 1994.

MORORÓ, L. P. A influência da formação continuada na prática docente. Educação \& Formação, v. 2, n. 4, p. 36-51, 2017. Disponível em: https:// revistas.uece.br/index.php/redufor/article/view/122/105 Acesso em: 10 de out. 2019.

MORTATTI, M. R. A "querela dos métodos" de alfabetização no Brasil: contribuições para metodizar o debate. Acolhendo a Alfabetização nos Países de Língua Portuguesa, v. 8, n. 14, p. 74-98, 2014. Disponível em: http://www.revistas.usp.br/reaa/article/view/85962 Acesso em: 10 de out. 2019.

PEREIRA, A. C.; RIBEIRO, C. S. J. A culpabilidade pelo fracasso escolar e a interface com os "problemas de aprendizagem" em discurso. Educação \& Formação, v. 2, n. 5, p. 95-110, 2017. Disponível em: https://revistas. uece.br/index.php/redufor/article/view/138/121 Acesso em: 10 de out. 2019.

PEREZ, M. C. A. Infância e escolarização: discutindo a relação família, escola e as especificidades da infância na escola. Práxis Educacional, v. 8, n. 12, p. 11-25, 2012. Disponível em: http://periodicos2.uesb.br/index. php/praxis/article/view/684 Acesso em: 11 abr. 2020.

PERROT, M. Os excluídos da história: operários, mulheres e prisioneiros. Tradução de Denise Bottmann. 7 ed. Rio de Janeiro: São Paulo: Paz e Terra, 2017. 
PIAGET, J. A Construção do Real na Criança. Rio de Janeiro: Zahar, 1975.

PIAGET, J. Psicologia e Pedagogia. Rio de Janeiro: Forense, 1970.

PLANCHARD, É. A pedagogia contemporânea. Coimbra: Coimbra Editora, 1975.

QEDU. Cascavel: Ideb 2017 por escolas. 2017. Disponível em: https:// www.qedu.org.br/cidade/5306-cascavel/ideb/ideb-por-escolas . Acesso em: 17 maio 2020.

SANCHIS, I. P.; MAHFOUD, M. Construtivismo: desdobramentos teóricos e no campo da educação. Revista Eletrônica de Educação. v. 4, n. 1, p. 18-33, 2010. Disponível em http://www.reveduc.ufscar.br/index.php/ reveduc/article/view/120/86. Acesso em: 23 maio 2020.

SANTO, E. R. E; OLIVEIRA JÚNIOR, O. B. Sistema de escrita alfabética: problematizando um sistema conceitual. Revista Educação e Emancipação, v. 13, n. 1, jan./abr. p. 288-313, 2020. Disponível em: http:// dx.doi.org/10.18764/2358-4319.v13n1 p288-313 Acesso em: 17 maio 2020.

SMYTH, E.; HAMEL, T. The history of initial teacher education in Canada: Québec and Ontario. Educação \& Formação, Fortaleza, v. 1, n. 1, p. 88109, 2016. Disponível em: https://revistas.uece.br/index.php/redufor/ article/view/93/92 Acesso em: 10 de out. 2019.

SOARES, M. Alfabetização: a questão dos métodos. São Paulo: Contexto, 2017.

SOARES, M. Letramento: um tema em três gêneros. Belo Horizonte: Autêntica, 1998.

SOLÉ, I. Alfabetização. In: SOLÉ, Isabel. Estratégias de leitura. Porto Alegre: Artmed, 1998. p. 50-51.

TANCREDI, R. M. S. P.; REALI, A. M. M. R. O que um mentor precisa saber? Ou: Sobre a necessidade de um mentor construir uma visão multifocal. Revista Exitus, v.1, n. 1, 2011. Disponível em: http://www.ufopa.edu. br/portaldeperiodicos/index.php/revistaexitus/article/view/203 Acesso em: 10 de out. 2019.

VASCONCELOS, J. G.; FIALHO, L. M. F.; LOPES, T. M. R. Educação e liberdade em Rousseau. Educação \& Formação, v. 3, n. 8, p. 210-223, 2018. Disponível em: https://revistas.uece.br/index.php/redufor/article/ 
view/278/206 Acesso em: 10 de out. 2019.

VASCONCELOS, L. M.; FIALHO, L. M. F.; MACHADO, C. J. S. Facetas da (im) potência viril na Revista Careta: educação e masculinidades no Estado Novo (1937-1945). Acta Scientiarum Education, v. 40, p. 1-12, 2018. Disponível em: http://periodicos.uem.br/ojs/index.php/ActaSciEduc/ article/view/41145 Acesso em: 8 ago. 2019.

WASCHINEWSKI, S. C.; RABELO, G. Aprovar para modernizar: primeiro plano estadual de educação de Santa Catarina (1969/1980) e o sistema de avanço progressivo. Revista Tempos e Espaços em Educação, v. 12, n. 30, p. 139-154, 2019. Disponível em: https://seer.ufs.br/index.php/ revtee/article/view/9384 Acesso em: 10 de out. 2019.

YIN, R. K. Estudo de caso: planejamento e métodos. Tradução Daniel Grassi. 2 ed. Porto Alegre: Bookman, 2001.

Recebido em: Maio/2020

Aceito em: Julho/2020 